\title{
THE DECLINE OF PUBLIC AND PRIVATE TRUST: THE MORAL CRISIS IN AMERICA
}

\author{
KENNETH ThOMPSON* \\ I \\ The IDEA OF Trust in Religion
}

Throughout history the idea of trust has been a cardinal tenet of religion, politics and human relations. In ancient Judaic times, the Biblical prophets called on man to place ultimate trust in God saying:

Thus saith the Lord; Cursed be the man that trusteth in man and maketh flesh his arm, and what heart departeth from the Lord. . . Blessed is the man that trusteth in the Lord. ... The heart is deceitful above all things and desperately wicked: who can know it?

In Reinhold Niebuhr's words:

... the basis of . . . trust [for the Christian religion] is not in any of the constructs of human genius or any of the achievements of human diligence which arise periodically to imposing heights and tempt men to put their trust in their own virtues and abilities. ${ }^{2}$

Christian trust resides in God and God's laws, not in man's ability to fulfill those laws. Yet such is man's pride that he places his trust in false gods: ${ }^{3}$ material abundance, human progress, the perfectibility of human reason, nation, culture, church or class.

Optimism about man's nature was for Niebuhr more dangerous to faith than despair over man's lot, because few men are willing to accept permanent despair. ${ }^{4}$ Instead they build little worlds of meaning and trust around themselves, existing only as small fragments of the cosmos. In the midst of chaos and confusion, men seek hope in self-sufficiency buttressed by optimistic creeds of progress, salvation through a political leader or social class, or faith in some social utopia. ${ }^{5}$

For Niebuhr, man's faith and trust in the fragmentary communities of existence has characterized societies since the earliest chapters of human history. Primitive man placed his trust in the tribe or the nation in order to propitiate the gods. ${ }^{6}$ The complexity of such trust, however, was illustrated in the concept of the chosen

\footnotetext{
Copyright $\mathcal{O} 1981$ by Duke University

* Director, Miller Center for Public Affairs At The University of Virginia

1. Jeremiah 17: 5-9 (King James Version of the Bible)

2. R. Niebuhr, Beyond Tragedy: Essays on the Christian Interpretation of History 113 (1941).

3. Id., at 114 .

4. Id., at 115 .

5. Id.

6. Id., at 116 .
} 
nation or chosen people. The tribe or nation legitimized its claim on man's loyalty by maintaining that God had chosen it to realize his purposes on earth. Yahweh's relation to the Hebrew people as a chosen race is illustrative of such faith in other primitive cultures. The tribe or the nation, whatever its accomplishments, required a link with some transcendent being.

Even the most optimistic creeds including Greek philosophy and the later utopians that worship some attribute of human nature hedge against man's failures by seeking reference points outside human history. Breakdowns and catastrophes in a nation's history were so commonplace that trust depended on something more permanent than national destiny or political success. "The Hebraic prophetic movement found a source of the meaning of human existence which not only transcended any possible chaos in history but actually predicted catastrophe as the inevitable consequence of man's sin against life and God."7 Religion for the prophets was more than a compensation for failure and defeat. Nations as men are mortal. ${ }^{8}$ To trust the virtue of collective man is therefore as false as to trust wicked and deceitful individual man. Religion establishes a source of trust outside the chaos and destruction of human societies.

This source of meaning and of ultimate trust has been undermined or compromised by a succession of historical events. "The faith of early Christianity was apocalyptic,"9 awaiting the second coming of Christ. When this vision was disappointed, a devolution of the source of trust occurred as Christianity made its peace with the secular and political world. It became a "new cement of social cohesion for a Roman Empire." ${ }^{10}$ It served temporarily to give coherence to a political system that had by then begun to decay. Faith in God intermingled with and became corrupted by faith in Rome and in the citizen of Rome.

St. Augustine sought to rescue Christianity from this union with an Empire facing destruction. He offered Christians an interpretation of their faith based on a City of God which was eternal and an earthly city doomed by "self-love in contempt of God." "I Whether in victory or defeat, the earthly city was corrupted by man's self-love and trust in himself. But Christianity would survive the fall of Rome because its home was the heavenly city.

Ironically, however, Augustine contributed to a further decline in religious faith and trust. In part, his writings were an answer to Roman pagans who charged Christianity with having weakened faith in the Empire, thereby causing its collapse. The decline of the Roman Empire was due, he argued, not to the rise of Christianity but was rather the consequence of man's fall. ${ }^{12}$ Regardless of the shape of human institutions, the reality of finite man refusing to concede his finiteness would lead to society's decay. "It is vain that men look for beatitude on earth or in

7. Id., at 118 .

8. Id.

9. Id., at 119 .

10. Id.

11. Id., at 120 .

12. Saint Augustine, The City of God (tr. Marcus Dods), Bk. XV, ch. 4 (Mod. Lib. 1950). 
human nature."13 Every man as he strives for power shows himself willing to inflict injury and loss on every other man. It is true that man was given power over every living creature but he was corrupted as he sought to dominate other men. Rome sought not wealth and comfort but pursued nobler goals such as glory, honor and fame. Trusting to themselves, Romans came to rule the whole civilized world. The glory of conquest and subjugation of non-Romans by force carried a fateful price. Glory and honor were civilizing objectives because their attainment required society's homage and respect. However, for Rome the desire for glory was overwhelmed by the desire for naked power. In Augustine's words, “. . . he who is a despiser of glory, but is greedy of domination, exceeds the beasts in the vices of cruelty and luxuriousness." 14 The quest for glory, honor or fame makes men eager to be praised and well thought of by other men; those who seek domination over others commit the worst crimes and atrocities.

For Augustine, then, fallen men cannot achieve perfect trust; in every community from the family to the empire, suspicions and quarrels intrude. Even within the family - man's most intimate community - treachery and deceit replace trust. Friendships are flawed by man's selfishness and his failure to perceive and respect the hopes and fears of others. Even self-knowledge is marred by the ruling passions. Peace is at best a "doubtful" interlude "between conflicts." 15

The further decline in trust resulted paradoxically enough from Augustine's vision of the City of God. He set that city against man's earthly city; the rule of the former was "love of God in contempt of oneself" but of the latter "self-love in contempt of God." A small minority of mankind has been chosen to receive eternal salvation. ${ }^{16}$ "These men ... [and the good angels] constitute the City of God, and at the end of time, after the resurrection of the body, they will live forever in perfect peace and happiness and in enjoyment of God." 17

The human part of this city is a single society spread throughout the world.

This heavenly city, then, while it sojourns on earth, calls citizens out of all nations, and gathers together a society of pilgrims of all languages, not scrupling about diversities in the manners, laws, and institutions whereby earthly peace is secured and maintained, but recognising that, however various these are, they all tend to one and the same end of earthly peace. ${ }^{18}$

The visible church is more closely related to the Eternal City than any other human institution, but its members include both the reprobate and the elect. ${ }^{19}$ At several points, Augustine appeared to say that the boundaries of the church are not coterminous with the Heavenly City. The members of the City of God are pilgrims or sojourners in this life who long for the end of history and the time

13. Id.

14. Id., at 172 (Bk. V, ch. 19).

15. H. Deane, The Political and Social Ideas of St, Augustine 158 (1963).

16. Id., at $19,23-24, \& 37$.

17. Id, at 28.

18. Saint Augustine, supra note 12, at 696 (Bk. XIX, ch. 17).

19. Deane, supra note 15 , at 29. 
when they join the Eternal City. Others such as Niebuhr and his students were to contend that Augustine confused the two cities.

For Niebuhr, Augustine, as he is sometimes interpreted, erred by identifying the Heavenly City with the church. ${ }^{20}$ This error led Augustine to place too much trust in man, in this instance the "redeemed man in the church." 1 Even redeemed man who lives by grace remains finite, sinful, and subject to historical aberrations of his own generation and to the ambitions and pride of special groups and classes. $^{22}$ The church remains a human institution dependent on "those classes of society who can most easily support it" and who benefit from those injustices that serve it and the church. ${ }^{23}$ In Niebuhr's view: "Augustine, in short, was responsible for the great heresy of Roman Catholicism, the heresy of identifying the church with the Kingdom of God and of making unqualified claims of divinity for this human, historical and relative institution."24

Medieval civilization expressed both the strengths and the weaknesses of Augustine's theology. Trust in God came to mean trust in the church and the attainments of medieval Europe arose out of its religious foundations. ${ }^{25}$ Papal leaders of the moral stature of Gregory VII and Innocent III $^{26}$ left a legacy of faith that inspired the progress of civilization. Yet as temporal rulers the Popes fell prey to the pretensions of all rulers. "Wherever religion is mixed with power and wherever the religious man achieves power, whether inside or outside the church, he is in danger of claiming divine sanction for the very human and frequently sinful actions, which he takes and must take." ${ }^{27}$ Cursed be the man, Niebuhr concluded paraphrasing Jeremiah, who places his trust in the earthly church. ${ }^{28}$ Christians in medieval history overlooked the peril of mixing too uncritically their trust in God and trust in man.

Protestantism, in Niebuhr's view, was born in rebellion against this Catholic heresy. It struggled to free itself from the pretensions of believing that man could achieve the Kingdom of God by saintliness and virtue. The Protestant reformer trusts the grace of God while distrusting the goodness of man. ${ }^{29}$ Yet Protestantism falls victim to another temptation. It places its trust in "the pious man." ${ }^{\text {"30 }}$ Protestantism rests its faith not in Christian civilization but in the pious individual who, interpreting the Scriptures without intermediaries, is capable of knowing God's will. If only other men were as pious as the individual Christian, God's Kingdom

\footnotetext{
20. Niebuhr, supra note 2 , at 121 .

21. Id.

22. Id.

23. Id

24. $I d$.

25. Id.

26. Id., at 122 .

27. Id.

28. Id.

29. Id., at 123 .

30. Id.
} 
would come to the world. Niebuhr asks, "What have been the historical consequences" 31 of Protestant individualism? He responds:

Sometimes Protestant piety has degenerated into barren orthodoxy; sometimes into Puritan self-righteousness. . . Sometimes the very relative moral code of lower middle-class life ... [becomes] the sign and the proof of a 'God-fearing' man in Calvinistic Protestantism. Sometimes the ethics of money-getting is sanctified in the same manner. On occasions the pious Protestant is as certain that his civilisation (capitalism) is God's peculiar civilisation as the Catholic was certain of feudalism. ${ }^{32}$

Niebuhr proclaimed with the prophets a judgment on Protestantism, which he found wanting as all other religions: "Cursed be the man that trusteth in man," even when he is pious man, or perhaps, especially when he is pious man. ${ }^{33}$

\section{II}

\section{The Idea of Trust in Politics}

If religious thinkers have questioned the possibility of placing one's trust in man, the literature of practical politics abounds with skeptical references to trust. A French proverb from an anonymous source reads: God save me from him I trust. ${ }^{34}$ In a passage dated May 26, 1783, Boswell's Life of Samuel Johnson records the following: "I would rather trust my money to a man who has no hands . . than to a man of the most honest principles." 35 An Italian proverb reads: Trust was a good man, but Trust-not was a better. ${ }^{36}$ A Yugoslav proverb warns: Trust only yourself and your own horse. ${ }^{37}$ An English proverb of the 15th century proclaims: In trust is treason. ${ }^{38}$ Thomas Fuller writing in 1732 in Gnomologia: "If we are bound to forgive an enemy we are not bound to trust him." 39 Shakespeare echoes in 1599 in Henry V, II, a similar view: "Trust none; For oaths are straws, men's faiths are wafercakes. . . ."40

If political writers and politicians have placed limits on the possibility of trust, they have sought to redefine its role in more specific and pragmatic terms. The nineteenth century Italian nationalist, Count Camillo Di Cavour, is quoted as having counseled political leaders: The man who trusts other men will make fewer mistakes than he who distrusts them. ${ }^{41}$ For Niccolò Machiavelli in his advice to the prince, the appearance of trust was essential for success in politics. Trust in politics,

31. Id., at 124 .

32. Id.

33. Id.

34. H. Mencken (ed.) A New Dictionary of Quotations on Historical Principles from AN. CIENT AND MODERN SOURCES 1219 (1976).

35. Id.

36. Id., at 1220 .

37. Id.

38. Id., at 1219 .

39. Id.

40. Id.

41. Id. 
however, was subject to constraints, for as Machiavelli wrote in the famous eighteenth chapter to The Prince:

How laudable it is for a prince to keep good faith and live with integrity, and not with astuteness, every one knows. Still the experience of our times shows those princes to have done great things who have had little regard for good faith, . . and who have ultimately overcome those who have made loyalty their foundation. . . . Therefore, a prudent ruler ought not to keep faith when by so doing it would be against his interest, and when the reasons which made him bind himself no longer exist. If men were all good, this precept would not be a good one; but as they are bad, and would not observe their faith with you, so you are not bound to keep faith with them. ${ }^{42}$

The disputations among the interpreters ${ }^{43}$ of Machiavelli have centered around passages such as these, some arguing that cynicism dominated his views, others insisting that his intention was merely to warn against the danger of weak governments that were too virtuous to have recourse to power, still others that the Machiavellian view was standard in its day. A similar dispute surrounds the oftquoted remark of the British Ambassador, Sir Henry Wotton, who defined an ambassador as "an honest man who is sent to lie abroad for the good of his country." at Augsburg." monarch, James I, that he should continue in diplomatic service.

Yet the image of the diplomat as "an honorable spy" persisted. ${ }^{46}$ Diplomatists of the sixteenth and seventeenth centuries provided grounds for the suspicion that they left aside private morality when they entered public service. In Sir Harold Nicolson's words: "They bribed courtiers; they stimulated and financed rebellions; they encouraged opposition parties; they intervened in the most subversive ways in the internal affairs of the countries to which they were accredited; they lied, they spied, they stole." ${ }^{7}$ Yet Nicolson, looking for the permanent qualities requisite for the good diplomatist in every age, put truthfulness first alongside intelligence and character. Acknowledging that "The worst kind of diplomatists are missionaries, fanatics and lawyers; the best kind are the reasonable and humane sceptics," 48 Nicolson modified Wotton's statement by adding: the diplomat must return to negotiate another day. ${ }^{49}$ His reputation for credit and confidence in the long run will prove more lasting than his momentary success through deception. For the negotiator should recollect that he is likely for the rest of his life to be judged by whether men are ready to trust his word. Trust is in this regard the cement of

42. N. Machiavelli, The Prince and the Discourses (tr. L. Ricci, rev. E. Vincent) 63-64 (Mod. Lib. 1940).

43. I am thinking here primarily of the writings on Machiavelli by Leo Strauss, Herbert Butterfield,

Hans J. Morgenthau, and Max Lerner.

44. H. Nicholson, Diplomacy 21 (3d ed. 1964).

45. Id.

46. Id., at 20 .

47. Id.

48. $l d$, at 24 .

49. Id. 
diplomacy, the nexus of negotiations, if the diplomat is to return to negotiate another day.

What is true of diplomacy is true of politics. Lying is not, in the long run, good politics either with your friends or enemies. It is better not to say anything than to lie. A student of the political machine of the late Richard Daley in Chicagoperhaps the most successful political machine in the history of American politics-has asserted that Daley and his immediate associates almost never lied. ${ }^{50}$ Successful politicians will not promise to do anything unless they can deliver it. They are wiser not to say anything. In this respect, it is possible that politicians in Chicago are no different from politicians in Peking or Moscow or elsewhere in the world. A precinct captain will not promise a constituent he will do something unless he can get it done. A ward committeeman will not promise a job to a precinct captain unless he can deliver it. Mayor Daley did not make promises unless he was confident he could back them up. Politicians of this school operate on the principle that it is better not to lie to your friends because, if you lie, they will never trust you again. In the same way, it is also better not to lie to your enemies because that too is dangerous. For political reasons, they need to be able to rely on your word. Therefore while people may lie in politics, practice shows it is not good politics.

At the same time, politics and diplomacy offer countless examples of selective truth-telling. It is not only politicians and diplomatists who find it prudent to extract some parts of the truth and omit others. Family life suffers when a mature and experienced father takes as his guide with his children the maxim to tell the truth, the whole truth and nothing but the truth. Selective truth-telling may be an essential requirement for bringing young people to maturity. The strong father may wish not to throw all his burdens and professional problems on his family. It was Clark Kerr, I think, who once observed: I do not expect the President of my university to tell the worst things about the university. Referring to public servants, another observer has noted that saying "honesty is the best policy" is one of the most immoral statements that has ever been made. It implies that the only reason for honesty is that the civil servant has been paid for his honesty and that his capacity for judgment has no intrinsic moral base. On August 3, 1914, the German Chancellor Von Bethman-Hollweg declared that the treaty guaranteeing the neutrality of Belgium was "a scrap of paper." His statement was accurate, objectively, but it was a politically stupid declaration if true. The Chancellor's values as an honest man clashed with his interest to conceal what Germany was doing.

As the crises of international politics intensify, the pressures on ethics become greater. As concern for national survival grows more urgent, the pressures to violate what are recognized in personal life as moral principles multiply. In the Second World War, a radical shift occurred in attitudes toward morality. The historians of the Franco-Prussian War of 1870 in Prussia and France respectively

50. Rakove, Power, Self-Interest and Chicago Politics, in K. Thompson \& R. Myers (ed.), Truth and Tragedy: A Tribute to Hans Morgenthau 112-24 (1977). 
had described, on one side, the widespread popular indignation against the guerrilla actions of the French and, on the other side, the military actions of the Germans against the French. In World War II, the legal and moral distinctions between civilian and military personnel were obliterated for both Axis and Allied powers. The technology of warfare was in part responsible for the change, but so was a general decay in respect for human life stimulated by technology.

The attitudes in international society with respect to killing resemble lawlessness on the frontier. In modern civilized communities, men do not carry guns for self-protection as they move about in society. However, that need existed for long periods of history when the moral constraints against killing were hedged about by the requirements of survival. The condemnation of killing in present-day civilized nations has become virtually an absolute prohibition. Once society loses its ability to protect its citizens and self-defense replaces an effective system of law and order, however, the moral rules against killing are bound to change. The individual must provide for himself the means of protection against being killed by someone with fewer moral scruples than himself. In short, circumstances affect the relevance and application of absolute moral principles. What is true of killing is true to a still greater extent of lying and therefore of the context in which trust can be preserved in politics and diplomacy. The normative function of a moral code remains intact but its compulsive force, the actual normative force of that code, is qualified by the situation. Something more than slavish conformity to an absolute moral code is essential to trust, for such conformity is unlikely even in the best of worlds.

\section{III}

\section{The Idea of Trust in Human Relations}

The problem of trust in human relations confronts difficulties not too dissimilar from those in religion and politics. A host of far-reaching social changes has compounded the problem. For one thing, morality and trust involve primary relations between two persons, yet modern day society has become increasingly a society based on secondary relations. Trust depends to an important degree on face-to-face relations; but, with the kaleidoscopic movement of peoples and groups across a broad social and geographic spectrum, such relations are becoming less and less possible. I may dislike my neighbor but neighborliness gives me the chance to know him as I cannot know a stranger. My children's life style may offend me but, given compassion and cultural empathy, I have a chance of understanding the reasons of their folkways. In my childhood, I learned some of the causes for the ancient maxim: never trust a stranger. Much as it offended my youthful liberal outlook, the disruptions of family life in a small midwestern town by strangers who called on my father, a clergyman, to rescue them from human predicaments that were beyond salvation led me to qualify my early view. Today we are, as sociologists remind us, a nation of strangers. The nation's mobility has scattered families over three thousand miles. Trust all too often must be taken on faith. Personal relations are ever more complex because of the transitory character of most human contacts. 
The weakening of the hold a common religion once had on people further complicates the basis of trust. The society operates on many value systems, not a single unified and widely accepted system of religious and moral beliefs. We are a pluralist society of many religions, some of which are more threatening to other religious systems than no religion at all. Catholics and non-Catholics, Christian Scientists and non-Christian Scientists, charismatic Christians and non-charismatic Christians are as likely to be arrayed against one another as are Christians and non-Christians. Young people question the foundations of those religions that stand in the way of their unfolding life-styles. Religion which once was a source of unity threatens to become a profoundly divisive force as liberal Jews oppose orthodox Catholics on urgent social issues like abortion.

We are also a divided people on the issues of business and government. The business ethic is rooted in values such as profits and production; the public ethic speaks of welfare and helping the poor. ${ }^{51}$ The one ethic tends to be tough-minded, growth-oriented and committed to freedom; the other calls for planning to meet human needs and new social problems and is reconciled to controls. The former looks finally to the bottom line of profits and losses; the latter calls on society to recognize neglected human problems. Given the wide gulf that separates business and government, the call for understanding and trust too often falls on deaf ears.

Society is also divided morally and intellectually along major group lines that make trust more difficult to achieve. Periodically, we call on the people to trust this dominant intellectual or political movement or that representative social group. Trust science, we say; the fruits of scientific achievements span our common life from medical advances to placing man on the moon. Yet the most scientific nation in Europe initiated World War II and the West's scientific prowess has led to the building of weapons that threaten all mankind. Trust reason and education, others proclaim, and trust mass communication. Yet as Niebuhr argued: "The ubiquity of the written word, which, in the opinion of Condorcet, would bring salvation to the world, can spread vulgarity and prejudice as quickly or more quickly than it can spread enlightenment." ${ }^{2}$ Trust intelligence, yet ". . . intelligence merely raises all the potencies of life, both good and evil." ${ }^{, 53}$ Trust intelligence joined with piety, says liberal Protestantism, yet such a marriage, as with projects of the 1930's advanced by the champions of Social Gospel, may lead to an ennervated sentimentality. For: “. . . piety may rob the intelligent man of his critical vigour and intelligence may destroy the indispensable naïveté of all robust religion." 54

Trust youth was the rallying cry during and after the World Wars and America's Vietnam War. Old men perpetuate wars and accept ancient evils. Old men are tired, timid and cowardly about change. Youth is heroic and self-sacrificing, capable of giving the world a fresh start. Youth brings fresh conscience to man's problems

51. Milton Friedman has taken the first view and John $K$. Galbraith the second position.

52. Niebuhr, supra note 2 , at 125 .

53. Id., at 126 .

54. Id. 
and, spurred by moral outrage, uproots civilization's gravest evils. Yet youth, lacking a sense of history, is also impatient and prideful. Youth provides the most fanatical disciples for the culture's most hysterical political and religious movements. Others say trust the rich, who should not be tempted by corruption. Yet from "robber barons" at the turn of the century to corporate leaders offering payoffs for new economic opportunities abroad, the rich have not distinguished themselves for their absolute incorruptibility.

Trust the poor, social reformers urge, for the poor have little and deserve much. Yet the poor man who gains power becomes as untrustworthy as the rich. The reasons are those cited by Niebuhr, who most consistently served the poor in his ministry than any other twentieth century theologian:

If the poor man is generally trusted... he will achieve the power to overturn society and build a new social order. He will then cease to be the poor man and will become the powerful man. The prophets who led him in the wilderness will become the priest-kings of the new order. The new social order may be immeasurably better than the old one but it will not be free of the temptation to corrupt and to misuse power. ${ }^{55}$

Surely this has been true of the Marxist paradise of the poor, the Soviet Union. The prophet who has gained power will kill his fellow-prophets, as Stalin did Kamenev and Zinoviev, or exile them, as he did Trotsky. ${ }^{56}$ Too unqualified a faith in the poor man-labor, the proletariat or the disadvantaged-will generate an equilibrium of forces making the poor man untrustworthy.

Trust in human relations depends on something broader and more fundamental than calling forward one movement or group to be the bearer of trust. Every movement and every group has its strengths and weaknesses. Each has its contribution to make. But in Niebuhr's critical view:

... there is no form of human goodness which cannot and will not be corrupted, particularly in the day of its success. Let the wise man destroy the superstitions of the priest and the poor man disprove the pride of the wise man; but then a new prophet must arise to convict the priest-king of the poor of the perennial sins of mankind to which he is also subject. ${ }^{57}$

\section{IV \\ The Present Crisis of Trust}

Whatever the historical sources of trust, present day America faces a new crisis of confidence and trust. At one level, the historic problems are manifest in the unfolding of nationwide mistrust which has weakened the nation's confidence in itself and in successive Presidents. President Kennedy spoke of trusting a new generation of leaders who had taken up the torch from those who had led the nation in World War II and its aftermath. Yet even before the young President was struck down by an assassin's bullet, youth showed itself unable to resolve the

55. Id., at 130 .

56. Id.

57. Id., at 131 . 
nation's problems. Youth did not free the President from the blunder of an abortive invasion of Cuba in the Bay of Pigs nor an ill-fated confrontation with Premier Khrushchev in Vienna. President Johnson inaugurated more social legislation than any President in modern times but fell victim to the struggle in Vietnam, which more prudent national leaders had described as "too tough a nut to crack." President Nixon's rallying cry was trust "Middle America" but his administration was corrupted by its willingness to violate the law in its campaign against those who opposed its political objectives. President Carter proclaimed his determination to trust the people, but the tension between his populist tendencies and the necessities of governance proved a fateful stumbling block to his presidential leadership.

It would appear that public and private trust, if it can be restored at all, must depend on something more than the rather sentimental, inconsistent and unrealistic approaches of recent leaders. The first step toward mutual trust is a bold recognition of the limits of trust. If America has become a nation of strangers representing a diversity of interests, cultures and languages, then communication and understanding have become more difficult, thus calling to mind Augustine's oft-repeated wry comment that trust for a man with a stranger was less likely than with his dog. Interpersonal relations, which are more impersonal in an ever-more complex world, may for the foreseeable future rest on the most tenuous foundations. Trust that presupposes the absolute goodness of man is romantic optimism, and romanticism throughout human history has been transmuted into cynicism and disillusionment. Confidence in the goodness of life cannot rest on confidence in the goodness of man. Deep human trust means discerning the goodness of creation beneath all the corruptions of human nature.

Trust, in short, depends, for religious thinkers most of all, on a recognition that evil cannot overwhelm the good. A man's tranquility results from the knowledge that the evil which others show toward him is not very different from the evil he shows toward others, that the trust others betray calls to mind the trust to which he himself does violence. Belief that man is incapable of perfect trust should not lead to withdrawal, supernaturalism, or otherworldliness. The answer to trusting in others can never be found in removing oneself from others. Nor is cynicism an answer, for cynics judge others for falling short of their ideals but justify themselves for achieving norms they themselves construct. From a religious standpoint: "The best antidote for the bitterness of a disillusioned trust in man is disillusionment in the self. This is the disillusionment of true repentance." 58

Trust for political men depends on greater realism about the political ties that bind men together. "Interests never lie" was a political axiom that Churchill periodically invoked, quoting his ancestor Lord Marlborough. At one level, trust rests on what Churchill described as the one helpful guide in politics, honor. In international politics, honor leads a nation to keep its word and to act in accordance with its treaty obligations. Yet honor is a concept of political ethics, not of higher morality; or as Churchill wrote: "It is baffling to reflect that what men call honour

58. Id., at 132 . 
does not correspond always to Christian ethics. . . An exaggerated code of honour leading to the performance of utterly vain and unreasonable deeds could not be defended, however fine it might look." 59

The same Churchill drew together a grand coalition to thwart the expansion of Nazi Germany, maintaining that, as had been true for four hundred years, it was the common interest of the states of Europe "to oppose the strongest, most aggressive, most dominating Power on the Continent, and particularly to prevent the Low Countries falling into the hands of such a Power." 60 Churchill reasoned from common interest in concluding: "Therefore, it seems to me that all the old conditions present themselves again, and that our national salvation depends upon our gathering once again all the forces of Europe to contain, to restrain, and if necessary to frustrate, German domination." ${ }^{61}$ With the rise of Hitler, Churchill said bluntly he would make a pact with the devil himself to contain Germany's expansion and, shortly thereafter, Britain gave assistance to the Red Army's struggle to hold back the Nazi juggernaut. On negotiating with the Russians, Churchill, whom the Russians had charged tried to strangle Bolshevism at birth, prophesied that the Soviets could be counted on to keep their agreements provided they were in the Russian national interest.

For politics, therefore, trust is dependent on the interests of a statesman, a party or a nation. Once common interests are identified, for example in the avoidance of nuclear war, men and nations will keep their word, even across a deep ideological divide. Religion and politics come together in their evaluation of trust, in that neither depends wholly on the virtue and goodness of other men. Paradoxically, nations recognize that agreements are most needed, as with strategic arms limitations, precisely when trust is lacking. If trust is to be sustained, interests once identified must be adjusted, preserved and maintained. What is therefore required is continuing political and diplomatic contact and exchange with one another.

One other requirement deserves mention. At a much simpler level and even in a highly complex world, some men and nations are more trustworthy and deserving of trust than others. We know what we mean when we say a certain person can be trusted. The character and integrity of political leaders such as Washington and Lincoln and, in our day, Eisenhower invited trust. If character breeds trust, its opposite sows seeds of suspicion and mistrust even when men may be trustworthy. The restoration of public and private trust depends on man's reputation for being trusted, on his reputation in word and deed. Reestablishing trust once it has been weakened or lost is never easy, yet our private and public leaders in undertaking this task have some examples to follow and others to avoid. The sly and sinister political manipulator or crafty business dealer cannot help rebuild confidence. The good and decent man who keeps his word may do so. This task is one of utmost urgency for the people, the nation and the Presidency.

59. W. Churchill, The Gathering Storm 321 (1948) (The Second World War, Vol. I).

60. Id., at 207. Churchill is here citing his own private address to the Conservative Members Committee on Foreign Affairs, at the end of March, 1936.

61. Id., at 209. The same report is cited as in note 60. 